\title{
ANALISA KINERJA KEUANGAN PERUSAHAAN SESUDAH DAN SEBELUM RESTRUKTURISASI DENGAN METODE ECONOMIC VALUE ADDED (STUDI KASUS PT M)
}

\author{
Yoseano Adrianus \\ Program Studi Magister Manajemen Universitas Tarumanagara \\ ysadrian@gmail.com \\ Suwinto Johan \\ Program Studi Magister Manajemen Universitas Tarumanagara
}

\begin{abstract}
Maximize the profit, it was a belief that every financial worker knows in their mind while they work, even though in present day maximize the shareholder's equity is the belief. There are many measurements to analyze financial performance of a company and EVA (Economic Value Added) was add to measure the company financial performance within year 2009 until 2016. In this study, PT M one of the well-known holding group company in Indonesia has facing a financial struggle within the internal company under the holding. So restructuring was decision to do on 2013 as turning point of the financial company. The result of the test with Wilcoxon signed ranked test is said that there is no difference between the company do restructuring or not do it. In fact, the financial performance of the company gotten worse for the restructuring process, but it is very dilemmatic inside the holding because if PT M not do the restructuring, one of the major division will collapse and giving threat to the holding company.
\end{abstract}

Keywords: EVA, Restructuring, Financial Performance

\section{PENDAHULUAN}

Menurut Andries (2010), Nilai perusahaan maksimum merupakan tujuan utama dari perusahaan dalam sektor finansial, sebab dengan nilai kinerja keuangan yang baik maka sebuah perusahaan akan dikenal bonafide oleh masyarakat awam. Tolak ukur nilai perusahaan adalah saham yang dimiliki oleh para pemiliknya, sehingga tujuan utama dari perusahaan bukan lagi maksimalisasi laba melainkan memaksimalkan kekayaan para pemegang saham.

Salah satu alat ukur dalam menilai kinerja perusahaan adalah nilai yang positif daripada EVA (Economic Value Added) jika nilai EVA pada perusahaan adalah negatif maka perusahaan tidak menciptakan nilai yang baik pada kinerja keuangannya. McDaniel, Gadkari, dan Fiksel (2000), mengatakan bahwa ada tiga hal utama yang membedakan EVA dengan tolak ukur keuangan yang lain, yaitu:

1. EVA tidak dibatasi oleh prinsip keuangan yang berlaku umum

2. EVA dapat memberi dukungan pada keputusan dalam suatu Perusahaan, mulai dari investasi modal, kompensasi karyawan, dan kinerja unit bisnis.

3. Stuktur EVA yang sederhana membuatnya bisa digunakan oleh bagian departemen atau personil lain sebagai alat yang umum untuk mengkomunikasikan aspek yang berbeda dari kinerja keuangan.

Tujuan dari penelitian ini adalah untuk mengetahui bagaimana perhitungan EVA dilakukan dan mengetahui apakah terdapat peningkatan rata-rata kinerja keuangan setelah restrukturisasi dengan menggunakan perhitungan EVA. 


\section{TINJAUAN PUSTAKA}

Mardiyanto (2009) menyatakan bahwa restrukturisasi perusahaan adalah "perubahan struktur organisasi sebagai akibat ekspansi dan kontraksi usaha. Restrukturisasi akan diikuti pula dengan perubahan pada neraca perusahaan, baik disisi aktiva maupun pasiva”. Restrukturisasi yang dilakukan oleh perusahaan dapat dibedakan menjadi tiga jenis, yaitu merger, akuisisi, beli utang, dan divestasi. Menurut Djohanputro (2004), restrukturisasi dapat dikategorikan kedalam tiga jenis, yaitu :

1. Restrukturisasi portofolio/Aset

2. Restrukturisasi modal/keuangan

3. Restrukturisasi manajemen/organisasi

Brigham (2002) menyatakan bahwa EVA merupakan perkiraan laba yang sebenarnya dari kegiatan Perusahaan, dimana hasilnya akan berbeda dengan perkiraan laba akuntansi. EVA menggambarkan sisa penghasilan sesudah dikurangi dengan biaya modal, sedangkan laba akuntansi ditentukan tanpa memperhitungkan biaya modal. EVA memiliki batasanbatasan sebagai berikut:

1. Jika EVA positif, menunjukkan adanya nilai tambah bagi Perusahaan

2. Jika EVA sama dengan nol, hal ini menunjukkan posisi impas Perusahaan

3. Jika EVA negatif, menunjukkan tidak adanya nilai tambah bagi Perusahaan.

$\mathrm{EVA}=$ NOPAT - Cost of Capital

$\mathrm{EVA}=\mathrm{NOPAT}-(\mathrm{IC} \times \mathrm{WACC})$

Keterangan:

EVA = Economic value added

NOPAT $\quad=$ Net operating profit after tax

IC $\quad=$ Invested capital

WACC $\quad=$ Weighted average cost of capital

Brigham (2002) dan Sjahrial (2007) menyatakan WACC merupakan perhitungan biaya modal secara keseluruhan berdasarkan proporsi dari masing-masing komponen modal. Komponen-komponen modal terdiri dari utang, saham preferen dan modal sendiri (ekuitas), yang dapat dihitung dengan rumus:

$\mathrm{WACC}=\mathrm{WdKd}(1-\mathrm{T})+\mathrm{WpKp}+\mathrm{W} s \mathrm{Ks}$

Keterangan :

WACC $\quad=$ Biaya modal rata-rata tertimbang

Wd $\quad=$ Persentase utang terhadap total modal

$\mathrm{Kd} \quad=$ Biaya utang

$\mathrm{T} \quad=$ Tingkat pajak

Wp $\quad=$ Persentase saham preferan terhadap total modal

$\mathrm{Kp} \quad=$ Biaya saham preferen

Ws $\quad=$ Persentase ekuitas terhadap total modal

Ks $\quad=$ Biaya ekuitas

Brigham (2002), modal yang diinvestasikan dapat dirumuskan sebagai berikut :

IC $=$ NOWC + OLTA 
$\mathrm{NOWC}=(\mathrm{C}+\mathrm{AR}+\mathrm{Psd})-(\mathrm{AP}+\mathrm{Accr})$

Keterangan :

IC $=$ Invested Capital

NOWC $=$ Net Operating Working Capital

OLTA $=$ Operating Long Term Asset

$\mathrm{C}=$ Kas dan setara kas

$\mathrm{AR} \quad=$ Piutang

Psd = Persediaan

AP = Utang dagang

Accr = Biaya yang masih harus dibayar penghasilan

Brigham (2002), NOPAT adalah laba bersih yang diperoleh perusahaan setelah pajak

NOPAT $=$ EBIT $(1-$ Tax $)$

EBIT $=$ Earnings Before Interest and Tax

Untuk melihat ada tidaknya peningkatan rata-rata kinerja keuangan PT M dan perubahan yang terjadi dari tahap restrukturisasi, maka penulis melakukan uji hipotesis, sebagai berikut :

H0: $\quad$ PT M, tidak mengalami peningkatan rata-rata kinerja keuangan setelah

restrukturisasi.

$\mathrm{H} 0=\mu 1<=\mu 0$

H1: $\quad$ PT M, mengalami peningkatan rata-rata kinerja keuangan setelah restrukturisasi.

$\mathrm{H} 1=\mu 1>\mu 0$

\section{METODE PENELITIAN}

Penelitian ini dilakukan dalam bidang manajemen keuangan, khususnya kinerja keuangan PT M, jenis penelitian ini adalah event study untuk melihat ada tidaknya peningkatan rata-rata kinerja keuangan PT M.

Periode penelitian adalah dari tahun 2009 sampai 2016, dimana tahun 2009 sampai tahun 2012 adalah periode sebelum restrukturisasi dan 2013 sampai 2016 adalah periode setelah restrukturisasi. Data diambil dari laporan keuangan tahunan PT M tahun 2009 sampai 2016.

Metode yang dipakai peneliti dalam menentukan apakah restrukturisasi perusahaan dilakukan adalah dengan nilai EVA (Economic Value Added) sebagai alat ukur dalam proses restrukturisasi perusahaan.

Penelitian kinerja keuangan PT M menggunakan model Manajemen keuangan Economic Value Added (EVA). EVA mampu menjelaskan sisa penghasilan sesudah dikurangi biaya modal, sedangkan laba akuntansi ditentukan tanpa menghitung biaya modal sendiri.

Metode Wilcoxon merupakan uji statistic non parametrik paired sample $t$ test yang digunakan untuk menguji apakah ada perbedaan dari pada pasangan data tersebut. Uji Wilcoxon dilakukan dengan menggunakan software SPSS, dimana Program akan melakukan 
proses pemberian ranking dan memilah nilai positif dan nilai negatif. dengan kesimpulan jika nilai p-value (sig.) diatas 0.05 maka Hipotesis akan ditolak, dan sebaliknya jika nilai signifikansi dibawah 0.05 maka Hipotesis tidak akan ditolak. Sehingga pada studi kasus PT. $\mathrm{M}$ metode ini digunakan untuk melihat perbandingannya sebelum dan sesudah retsrukturisasi dilakukan oleh perusahaan.

\section{HASIL PENELITIAN}

Berikut adalah nilai hasil perhitungan dari komponen-komponen untuk EVA, yaitu WACC, IC, dan NOPAT disertai trend dari tahun ke tahun.

WACC: Hasil perhitungan rata-rata tertimbang penggunaan biaya modal secara keseluruhan dari periode 2009 sampai 2016 menunjukkan besarnya penggunaan biaya modal dari periode 2009 sampai 2016, yaitu sebesar 3.32\% di tahun 2009, 7.16\% di tahun 2010, $8.75 \%$ di tahun $2011,6.58 \%$ di tahun $2012,7.32 \%$ di tahun $2013,8.05 \%$ di tahun 2014 , $6.02 \%$ di tahun 2015 , dan $7.39 \%$ di tahun 2016 .

Tabel 1

Hasil perhitungan WACC PT M 2009-2016

\begin{tabular}{|c|c|c|c|c|c|}
\hline Tahun & Wd & Kdt & Ws & Ks & WACC \\
\hline 2009 & $77.28 \%$ & $1.16 \%$ & $22.72 \%$ & $10.67 \%$ & $3.32 \%$ \\
\hline 2010 & $27.23 \%$ & $0.19 \%$ & $72.77 \%$ & $9.76 \%$ & $7.16 \%$ \\
\hline 2011 & $24.92 \%$ & $5.46 \%$ & $75.08 \%$ & $9.84 \%$ & $8.75 \%$ \\
\hline 2012 & $28.49 \%$ & $3.57 \%$ & $71.51 \%$ & $7.78 \%$ & $6.58 \%$ \\
\hline 2013 & $24.02 \%$ & $1.26 \%$ & $75.98 \%$ & $9.23 \%$ & $7.32 \%$ \\
\hline 2014 & $25.74 \%$ & $1.24 \%$ & $74.26 \%$ & $10.40 \%$ & $8.05 \%$ \\
\hline 2015 & $35.26 \%$ & $-1.56 \%$ & $64.74 \%$ & $10.15 \%$ & $6.02 \%$ \\
\hline 2016 & $32.82 \%$ & $2.46 \%$ & $67.18 \%$ & $9.80 \%$ & $7.39 \%$ \\
\hline
\end{tabular}

Sumber : Olahan Penulis

Hasil perhitungan NOPAT memperlihatkan kinerja perusahaan pada periode 2009 sampai dengan 2016, dengan rata-rata sebelum restrukturisasi sebesar 1,535 Milyar Rupiah dan menurun menjadi 245 Milyar Rupiah pada periode setelah restrukturisasi. Akan tetapi bila dilihat secara tahun per tahun, periode setelah restrukturisasi adalah periode yang tidak konsisten, karena pada tahun 2013, Perusahaan meraih laba besar, yaitu 1,598 milyar, akan tetapi pada tahun-tahun berikutnya Perusahaan mengalami rugi yang besar, yaitu 647 milyar pada tahun 2014 dan 822 milyar pada tahun 2015, dan pada tahun 2016 , Perusahaan kembali mendapatkan laba sebanyak 851 milyar. 
Tabel 2

NOPAT PT M $2009-2016$

\begin{tabular}{|r|r|r|r|}
\hline \multicolumn{1}{|c|}{ Tahun } & \multicolumn{1}{|l|}{$\begin{array}{l}\text { Pajak } \\
\text { operasi }\end{array}$} & \multicolumn{1}{l}{$\begin{array}{l}\text { penghasilan } \\
\text { kini }\end{array}$} & \multicolumn{1}{l|}{ NOPAT } \\
\hline $\mathbf{2 0 0 9}$ & 673,849 & $(29,752)$ & 644,097 \\
\hline $\mathbf{2 0 1 0}$ & $5,411,405$ & $(37,317)$ & $5,374,088$ \\
\hline $\mathbf{2 0 1 1}$ & $(21,702)$ & $(47,793)$ & $(69,495)$ \\
\hline $\mathbf{2 0 1 2}$ & 253,326 & $(61,380)$ & 191,946 \\
\hline $\mathbf{2 0 1 3}$ & $1,800,830$ & $(201,936)$ & $1,598,894$ \\
\hline $\mathbf{2 0 1 4}$ & $(391,187)$ & $(256,757)$ & $(647,944)$ \\
\hline $\mathbf{2 0 1 5}$ & $(692,443)$ & $(130,346)$ & $(822,789)$ \\
\hline $\mathbf{2 0 1 6}$ & 954,604 & $(102,607)$ & 851,997 \\
\hline
\end{tabular}

Sumber : Laporan keuangan tahunan PT. M

Perhitungan IC akan didapatkan hasil 6,983 Milyar pada tahun 2009, 6,652 Milyar pada tahun 2010, 10,853 Milyar pada tahun 2011, 9,863 Milyar pada tahun 2012, 11,815 Milyar pada tahun 2013, 13,448 Milyar pada tahun 2014, 13,362 Milyar pada tahun 2015, 13,939 Milyar pada tahun 2016.

Hasil perhitungan IC, menunjukkan bahwa modal yang diinvestasikan dari periode 2009 sampai dengan 2016 mengalami kenaikan dari awal periode sampai dengan akhir periode penelitian. Hal ini menunjukkan bahwa Perusahaan terus menambah utang untuk tujuan operasional.

Tabel 3

IC PT M 2009 - 2016

\begin{tabular}{|r|r|r|r|}
\hline Tahun & \multicolumn{1}{|l|}{ Total utang } & \multicolumn{1}{l|}{ Total ekuitas } & \multicolumn{1}{l|}{ IC } \\
\hline $\mathbf{2 0 0 9}$ & $5,396,738$ & $1,586,463$ & $6,983,201$ \\
\hline $\mathbf{2 0 1 0}$ & $1,811,544$ & $4,841,331$ & $6,652,875$ \\
\hline $\mathbf{2 0 1 1}$ & $2,704,639$ & $8,148,738$ & $10,853,377$ \\
\hline $\mathbf{2 0 1 2}$ & $2,810,599$ & $7,053,073$ & $9,863,672$ \\
\hline $\mathbf{2 0 1 3}$ & $2,838,146$ & $8,977,127$ & $11,815,273$ \\
\hline $\mathbf{2 0 1 4}$ & $3,461,159$ & $9,987,121$ & $13,448,280$ \\
\hline $\mathbf{2 0 1 5}$ & $4,711,794$ & $8,651,183$ & $13,362,977$ \\
\hline $\mathbf{2 0 1 6}$ & $4,575,164$ & $9,364,471$ & $13,939,635$ \\
\hline
\end{tabular}

Sumber : Laporan keuangan tahunan PT. M 
Berdasarkan hasil perhitungan EVA, nilai keseluruhan EVA MLPL menunjukkan hasil yang tidak konsisten, jika dilihat dari periode sebelum dan sesudah restrukturisasi, maka periode sebelum restrukturisasi menjadi periode yang buruk bagi Perusahaan, dengan dimulai dari tahun 2009 bernilai 412 Milyar, dilanjutkan ke tahun 2010 yang naik ke angka 5,049 milyar, dan tahun 2011 kembali menurun ke angka negative 1,018 milyar. Pada periode setelah restrukturisasi, pada tahun 2013, efek restrukturisasi menunjukkan hal yang positif, dengan perolehan EVA bernilai 734 milyar, dari sebelumnya, pada tahun 2012, yang bernilai negatif 457 milyar. Tetapi pada tahun berikutnya Perusahaan gagal untuk mempertahankan nilai EVA tersebut dan mendapatkan nilai EVA pada 2014 sebesar negatif 1,729 milyar dan hal yang sama terjadi pada tahun berikutnya yaitu negatif 1,627 milyar pada tahun 2015, dan nilai EVA kembali naik ke angka negatif 178 milyar pada tahun 2016.

Tabel 4

Hasil Perhitungan EVA 2009 - 2016 PT. M

\begin{tabular}{|r|r|r|r|r|}
\hline Tahun & \multicolumn{1}{|l|}{ NOPAT } & \multicolumn{1}{l|}{ IC } & \multicolumn{1}{l|}{ WACC } \\
\hline $\mathbf{2 0 0 9}$ & 644,097 & $6,983,201$ & $3.32 \%$ & 412,231 \\
\hline $\mathbf{2 0 1 0}$ & $5,374,088$ & $6,652,875$ & $7.16 \%$ & $4,898,052$ \\
\hline $\mathbf{2 0 1 1}$ & $(69,495)$ & $10,853,377$ & $8.75 \%$ & $(1,018,879)$ \\
\hline $\mathbf{2 0 1 2}$ & 191,946 & $9,863,672$ & $6.58 \%$ & $(457,132)$ \\
\hline $\mathbf{2 0 1 3}$ & $1,598,894$ & $11,815,273$ & $7.32 \%$ & 734,120 \\
\hline $\mathbf{2 0 1 4}$ & $(647,944)$ & $13,448,280$ & $8.05 \%$ & $(1,729,860)$ \\
\hline $\mathbf{2 0 1 5}$ & $(822,789)$ & $13,362,977$ & $6.02 \%$ & $(1,627,430)$ \\
\hline $\mathbf{2 0 1 6}$ & 851,997 & $13,939,635$ & $7.39 \%$ & $(178,211)$ \\
\hline
\end{tabular}

Sumber : Olahan Penulis

Untuk mendukung perhitungan EVA mengenai apakah terjadi peningkatan rata-rata kinerja keuangan sebelum dan sesudah restrukturisasi, maka dilakukan pengujian secara statistic dengan metode Wilcoxon.

Hasil Perhitungan Wilcoxon

Ranks
\begin{tabular}{|l|l|l|l|}
\hline & $\mathrm{N}$ & $\begin{array}{l}\text { Mean } \\
\text { Rank }\end{array}$ & $\begin{array}{l}\text { Sum of } \\
\text { Ranks }\end{array}$ \\
\hline Sesudah-Sebelum & & & \\
Negative Ranks & & & \\
Positive Ranks & $2^{\mathrm{a}}$ & 3.50 & 7.00 \\
Ties & $0^{\mathrm{c}}$ & & 3.00 \\
Total & 4 & & \\
\hline
\end{tabular}

a. sesudah < sebelum

b. sesudah $>$ sebelum

c. sesudah $=$ sebelum

\begin{tabular}{|l|l|}
\hline & $\begin{array}{l}\text { sesudah } \\
\text { sebelum }\end{array}$ \\
\hline $\mathrm{Z}$ & $-.730^{\mathrm{b}}$ \\
\hline
\end{tabular}


Nilai Asymp. Sig adalah sebesar 0.465 dimana lebih besar daripada 0.05 sehingga dapat disimpulkan bahwa Hipotesisnya ditolak, yang berarti PT M, tidak mengalami peningkatan yang signifikan rata-rata kinerja keuangan setelah restrukturisasi. Sehingga langkah perusahaan dalam melakukan restrukturisasi sebenarnya kurang efektif karena tidak adanya perubahan signifikan dari tahun 2013 saat restrukturisasi dimulai sampai dengan tahun 2016 yang trend nya cenderung negatif.

\section{KESIMPULAN}

Metode EVA yang digunakan dalam penghitungan kinerja perusahaan sudah tepat, jika melihat rata-rata nilai EVA sebelum dan sesudah restrukturisasi dan didukung dengan hasil perhitungan Wilcoxon, maka tidak terdapat peningkatan rata-rata kinerja keuangan setelah restrukturisasi.

Hal ini diakibatkan oleh nilai NOPAT yang mengalami penurunan karena Perusahaan tidak dapat meraih keuntungan yang besar. Walaupun Terdapat kenaikan nilai EVA pada tahun setelah restrukturisasi, yaitu tahun 2013, namun perusahaan tidak mampu mempertahankan kinerja keuangan yang baik sehingga nilai EVA Perusahaan kembali turun pada tahun berikutnya, dan perlu beberapa tahun lagi untuk meraih nilai EVA yang positif kembali.

\section{SARAN}

Secara praktisi, PT M harus menerapkan analisa yang lebih komprehensif terutama dalam pengambilan keputusan perusahaan agar tidak salah menetapkan langkah. Dan secara akademis, penelitian berikutnya sebaiknya menggunakan data-data actual yang dapat dipercaya dan wawancara dari narasumber untuk konfirmasi keaslian data yang diambil terutama data dari perusahaan.

\section{TINJAUAN PUSTAKA}

Andries, Marina Estrella. (2010), Analisis kinerja keuangan perusahaan sebelum dan sesudah mengakuisisi dengan metode EVA (studi kasus pada PT Telekomunikasi Indonesia Tbk), Universitas Atmajaya Jakarta.

Brigham, Eugene F., and Davis, Philip. (2002). Intermediate financial management. Eigth edition southwestern thomson learning.

Djohanputro, Bramantyo. (2004). Perusahaan Berbasis Nilai. Strategi Menuju Keunggulan Bersaing. Jakarta: Rajawali Pers.

Mardiyanto, Handono. (2009). Intisari Manajemen Keuangan. Jakarta: Grasindo.

McDaniel, Jeff S., Gadkari, Vinay V., \& Viksel, Joseph. (2000). The Environmental EVA: A Financial Indicator for EH\&S Strategists, Corporate Environmental Strategy Vol. 7, No. 2.

Sjahrial, Dermawan. (2007). Manajemen Keuangan. Edisi pertama. Jakarta : Mitra Wacana 
